\title{
Internet i media mobilne w procesie studiowania - ocena wybranych aspektów kompetencji informacyjnych studentów
}

\section{KEYWORDS}

digital technologies, Internet, information resources, information literacy

\begin{abstract}
Katarzyna Borawska-Kalbarczyk, Internet i media mobilne $w$ procesie studiowania - ocena wybranych aspektów kompetencji informacyjnych studentów [Internet and mobile media in the study process - assessment of selected aspects of students' information literacy]. Kultura Społeczeństwo - Edukacja nr 2(20) 2021, Poznań 2021, pp. 43-69, Adam Mickiewicz University Press. ISSN 2300-0422, ISSN (Online) 2719-2717. DOI 10.14746/ kse.2021.20.3
\end{abstract}

Nowadays, the Internet has become one of the fundamental elements of functioning in society, also for pupils and students. Using the Internet requires specific skills related to obtaining and processing information. These are known as information literacy. They imply not only the ability to find the necessary information, but also to select reliable information that will meet the information needs of an individual. The article presents the results of research aimed at analyzing the process of using network information resources in the opinion of students. The results of the research made it possible to initially recognize and assess selected aspects of information competences in the studied group. Despite the perceived benefits and not imagining functioning without the Internet, the students showed a quite critical attitude in assessing the reliability of information obtained from the Internet.

* ORCID: https://orcid.org/0000-0003-4315-2226. 


\section{Wprowadzenie}

Informacja - stanowiąc dla ludzkości element niezbędny do budowania wiedzy i rozwoju cywilizacji - jest szczególnym obiektem poznawczym, z którego korzystamy w każdym aspekcie naszego życia. Jej wartość jest tak duża, że często traktuje się ją na równi lub w kategoriach wręcz przewyższających dobra materialne. W próbie odpowiedzi na pytanie, czym jest informacja, źródła naukowe w toku jej interpretacji przywołują dwa podstawowe ujęcia: datologiczny oraz infologiczny. Poziom datologiczny skupia uwagę na informacji jako czymś obiektywnym, niezależnym od jej użytkownika, natomiast poziom infologiczny uwypukla treść informacji dostarczanej przez komunikat, uwzględniając tym samym stosunek człowieka do procesu odbioru informacji (Stefanowicz, 2010). Ostatnie dekady rozwoju cywilizacji odznaczają się wyraźnym wzrostem potrzeby posiadania umiejętności sprawnego, szybkiego i skutecznego wyszukiwania informacji. Wiąże się to z dynamicznym i często niekontrolowanym przyrostem informacji, wynikającym z rozwoju cyfrowych technik jej produkowania, przesyłania i odbierania. Z tego powodu w dzisiejszych czasach, nazywanych „erą informacji”, niezwykle ważne stało się docieranie do jej źródeł oraz wykorzystywanie informacji - czynności rozumianych jako fundament złożonego procesu konstruowania wiedzy. W analizach Ewy Chmieleckiej (2004: 8) czytamy, że „informacja nie jest wiedzą, choć nie ma wiedzy bez informacji. Nie jest wiedzą także wtedy, gdy zostaje uogólniona i mówi o zbiorach. Nie jest wiedzą, ponieważ (...) choćby nawet dotyczyła wielkich zbiorów przedmiotów, to nie tworzy sensownej wizji świata. Nie daje nam wyjaśnienia świata. Nie zawiera w sobie odpowiedzi na pytanie «dlaczego? »". Kluczowego znaczenia nabiera więc jakość informacji. Wśród najważniejszych atrybutów można tu wymienić: prawdziwość - opisywanie stanu pewnej rzeczywistości w przyjętych jako dopuszczalne granicach błędu; aktualność - opisywanie teraźniejszego stanu pewnej rzeczywistości lub ostatniego możliwego do rozpoznania; wiarygodność jest miarą jej prawdziwości i aktualności; przyswajalność - możliwość wykorzystania przez odbiorcę bez konieczności wykonywania dodatkowych operacji przekształcających; relewancja - ważność przypisana informacji przez użytkownika; może zmieniać się w zależności od użytkownika (Galewski, 2012).

W celu zdobycia i weryfikacji informacji czy wymiany poglądów współcześnie jest najchętniej wykorzystywany Internet. Przenikliwie prawdziwie, z mistrzowską wrażliwością i poetycko ukazuje obraz Internetu Olga Tokarczuk (2019: 3), mówiąc: „świat jest tkaniną, którą przędziemy codziennie na wielkich krosnach informacji, dyskusji, filmów, książek, plotek, anegdot. Dziś zasięg pracy tych krosien jest ogromny - za sprawą Internetu prawie każdy może brać udział w tym procesie, 
odpowiedzialnie i nieodpowiedzialnie, z miłością i nienawiścią, ku dobru i ku złu, dla życia i dla śmierci. Kiedy zmienia się ta opowieść - zmienia się świat. W tym sensie świat jest stworzony ze słów”.

W opinii Dariusza Jemielniaka (2019: 24-25) „rewolucja internetowa unaoczniła ciekawe zjawisko: wielu ludzi wyraźnie preferuje szybkość i wygodę dostępu do informacji, przedkładając je nad jakość, weryfikowalność czy wiarygodność”. Digitalizacja społeczeństwa przyczyniła się do wykreowania specyficznego świata, który z jednej strony - posiadając możliwości kreatywnego wykorzystania cyfrowych narzędzi, z drugiej - sprzyja powstawaniu zagrożeń i niebezpieczeństw, wynikających z nadmiarowości i wszechobecności informacyjnej. Współcześnie nurtującym wyzwaniem staje się nie tyle wyszukiwanie potrzebnych informacji, ile umiejętność wyboru tych, które w możliwie największym stopniu zaspokoją potrzeby informacyjne danej osoby, będąc jednocześnie informacjami o najwyższej jakości.

Nie będzie nadużyciem opinia, że Internet stał się jednym z fundamentalnych elementów funkcjonowania w społeczeństwie dla uczniów i studentów. Obecni studenci (19-24 lata) są pokoleniem osób urodzonych po 2000 r. i wzrastających w dobie powszechnej kultury cyfrowej, która wkroczyła dynamicznie w fazę mobilności. Najbardziej oczywistym urządzeniem związanym z codziennym funkcjonowaniem jest smartfon, umożliwiający natychmiastową łączność z grupami znajomych i światem zewnętrznym. Wyniki raportu Digital 2020: Poland (Majchrzyk, 2020) wskazują, że liczba internautów w Polsce wynosi 30,63 mln udziału populacji, korzystający z Internetu: 81\%; roczny przyrost internautów: +2,3\% (686 tys.); natomiast dzienny średni czas spędzany w Internecie na dowolnym urządzeniu (na 1 użytkownika) to 6 godz. 26 min. Badacze ze Spicy Mobile, agencji prowadzącej badania aplikacji mobilnych, posługują się pojęciem mobinauci, dla podkreślenia roli urządzeń mobilnych w życiu użytkowników aplikacji internetowych. Dominujące cechy pokolenia współczesnej młodzieży podsumowuje Thomas Leoncini w rozmowie z Zygmuntem Baumanem: „(...) ciągle przesiadują w sieci, bez przerwy zerkają na telefon komórkowy, zawsze noszą ze sobą najnowocześniejsze i najpłynniejsze nie-miejsce na świecie (internet) i żyją w wiecznym kieszonkowym limbo, które nie istnieje, tworzy relacje tyleż trwałe, co nierzeczywiste" (Bauman, Leoncini, 2018: 70).

Niewątpliwie studenci są tą grupą społeczną, która najczęściej wykorzystuje Internet w procesie uczenia się (studiowania). Można stwierdzić, że w zasadzie niemożliwe jest wręcz ukończenie studiów bez technologii Internetu. Wielu wykładowców tworzy własne strony, udostępniając studentom materiały z wykładów, sieć służy jako szybki sposób komunikacji z prowadzącymi zajęcia, umożliwia śle- 
dzenie zmian w planie studiów, zapisywanie się studentów na zajęcia i seminaria oraz wiele innych. Nawet końcowy proces ewaluacji wiedzy studentów przeniósł się w świat wirtualny - tradycyjne indeksy zastąpione zostały cyfrowymi protokołami zaliczeń ćwiczeń i egzaminów. Nowoczesne technologie cyfrowe na czele z Internetem stały się więc współczesnym, nowym środowiskiem edukacyjnym, miejscem odbioru, przetwarzania informacji i uczenia się. Jednak umiejętność prawidłowego wykorzystania tej technologii nie jest tak powszechna, jak można by się spodziewać. Czasami niski poziom umiejętności cyfrowych ogranicza poprawny i efektywny sposób wykorzystania Internetu. Do nierzadkich praktyk wśród studentów należy chociażby tendencja do uproszczonego, powierzchownego korzystania z sieci. Powszechnie spotykany jest też brak poszanowania dla praw autorskich i dokonywanie plagiatów.

Można tu postawić pytanie, w jaki sposób studenci wykorzystują Internet jako edukacyjne środowisko uczenia się/studiowania? Tak sformułowany problem badawczy stał się podstawą zaprojektowania badań, których przedmiotem było wykorzystanie informacji pozyskiwanych z przestrzeni Internetu w procesie uczenia się w opinii studentów. Celem artykułu jest analiza procesu wykorzystywania informacyjnych zasobów sieci przez studentów oraz rozpoznanie i ocena wybranych aspektów kompetencji informacyjnych na podstawie użytkowania cyfrowej infosfery.

Badania empiryczne, których wyniki przestawiono w artykule, zostały zrealizowane w semestrze zimowym roku akademickiego 2019/2020, zatem tuż przed wybuchem pandemii koronawirusa. Obecny stan wiedzy wynikający z dynamicznego rozwoju sytuacji spowodowanej zakażeniami wywołującymi COVID-19 spowodował, że współczesna ocena znaczenia technologii cyfrowych, posiadania mediów mobilnych, dostępu do Internetu, a przede wszystkim kompetencji medialnych i informacyjnych nabiera odmiennego znaczenia. Złożoność sytuacji wywołanej pandemią sprawiła, że proces kształcenia uczniów i studentów - realizowany dotychczas w warunkach stacjonarnych - w ostatnich miesiącach społecznej kwarantanny funkcjonował wyłącznie dzięki technologiom cyfrowym. Światowa epidemia odsłoniła, jak ważne są odpowiednie kompetencje cyfrowe (informatyczne i informacyjne), niezbędne do uczestnictwa w zdalnej edukacji, tak uczniów/studentów, jak i osób prowadzących kształcenie przy pomocy platform i narzędzi cyfrowych. Wyrażam nadzieję, że rozważania zawarte w niniejszym tekście, koncertujące się głównie na ocenie i znaczeniu umiejętności informacyjnych użytkowników mediów cyfrowych, służyć będą poprawie jakości edukacji realizowanej $\mathrm{w}$ dobie społeczeństwa informacyjnego $\mathrm{w}$ cieniu pandemii. Te dwie płaszczyzny - wymagania społeczne współczesnego świata zdominowanego przez 
informację oraz wyzwania wynikające z zagrożeń COVID-19 sprawiają, że umiejętność dotarcia do informacji zyskuje współcześnie priorytetową rangę, stając się kompetencją kluczową.

\section{Information Literacy for Higher Education - koncepcja Amerykańskiego Stowarzyszenia Bibliotek Akademickich i Naukowych}

W nawiązaniu do powyższych rozważań ważną właściwością poznawczą młodych ludzi, wymuszoną przez zmiany informacyjne współczesności, jest umiejętność pracy z informacjami, których natłok jest doświadczeniem każdego z nas. W związku z tym ważnym jest kształtowanie kompetencji potrzebnych do selekcji, odbioru, interpretacji oraz weryfikacji informacji. Koncepcja kompetencji informacyjnych rozwija się od lat 70. XX w. dzięki intensywnemu wsparciu i promocji organizacji bibliotekarskich, takich jak American Library Association (ALA), American Association of School Librarians (AASL), Association of College and Research Libraries (ACRL), Chartered Institute of Library and Information Professionals (CILIP) czy Australian and New Zealand Institute for Information Literacy (ANZIIL). Rozwijane wówczas kompetencje informacyjnej związane były przede wszystkim $\mathrm{z}$ „potrzebą uzupełniania kompetencji pracowników przedsiębiorstw w celu efektywnego wykorzystania technologii informacyjnych i informacji w rozwiązywaniu problemów związanych z wykonywanym zawodem" (Rozkosz, 2017: 68).

Information literacy $\mathrm{w}$ literaturze rozważane jest jako pojemna koncepcja odnoszącą się do ludzkich umiejętności rozpoznawania potrzeb informacyjnych, wyszukiwania, oceny, wykorzystania i rozpowszechniania informacji w celu podejmowania decyzji, zdobywania wiedzy i doskonalenia umiejętności poznawczych (por. Boekhorst, 2003: 299). Akcentowana jest także potrzeba kształtowania właściwych postaw $\mathrm{w}$ rezultacie świadomego kontaktu $\mathrm{z}$ informacjami, co wiąże się z przestrzeganiem zasad prawnych i norm etycznych. Kompetencje informacyjne obecne w strukturze kompetencji jednostki stanowią ważną determinantę aktywnego uczestnictwa w życiu społecznym, ułatwiają podejmowanie decyzji, są orężem w walce $\mathrm{z}$ wykluczeniem informacyjnym oraz wzmacniają dążność do całożyciowego uczenia się, stanowiąc tym samym ważną przesłankę zmian ku nowej jakości edukacji (Borawska-Kalbarczyk, 2015).

W 2000 r. jedna z wymienionych wyżej organizacji - Amerykańskie Stowarzyszenie Bibliotek Akademickich i Naukowych (Association of College and Research Libraries) - opublikowała standardy związane z kompetencjami informacyjnymi - 
Information Literacy Competency Standards for Higher Education (Standardy kompetencji informatycznych dla szkolnictwa wyższego). W świetle dokumentu osoba wykształcona w zakresie information literacy potrafi: określić zakres potrzebnej informacji, efektywnie uzyskać wybrane informacje, krytycznie ocenić informacje i jej źródła, włączyć wybrane informacje do podstaw swojej wiedzy, efektywnie wykorzystać informacje do osiągnięcia określonego celu, zrozumieć ekonomiczne, prawne i społeczne problemy związane z wykorzystaniem informacji oraz pozyskiwać i wykorzystywać informacje w sposób etyczny i zgodny z prawem (American Library Association, 2000).

W ciągu piętnastu lat od opublikowania Standardów kompetencji informatycznych dla szkolnictwa wyższego bibliotekarze akademiccy i ich partnerzy w stowarzyszeniach szkolnictwa wyższego USA opracowali efekty uczenia się, narzędzia i zasoby, które niektóre instytucje wykorzystały, aby wprowadzić koncepcje i umiejętności w zakresie umiejętności informacyjnych do swoich programów kształcenia. Z uwagi na dynamikę przemian tak cywilizacji, jak i środowiska szkolnictwa wyższego, wraz z konsekwencjami niestabilnego i niepewnego ekosystemu informacyjnego, w którym wszyscy pracujemy i żyjemy, autorzy Standardów ... z 2000 r. zwracają uwagę na konieczność fundamentalnych zmian. Akcentują, że studenci mają większą rolę i większą odpowiedzialność w tworzeniu nowej wiedzy, zrozumieniu konturów i zmieniającej się dynamiki świata informacji oraz w etycznym wykorzystaniu informacji, danych i nauki. Wydziały pedagogiczne mają większą odpowiedzialność za projektowanie programów nauczania i zadań, które sprzyjają zwiększonemu zaangażowaniu w podstawowe idee dotyczące informacji w ich dyscyplinach. Na bibliotekarzach zaś spoczywa większa odpowiedzialność za identyfikację podstawowych pomysłów w zakresie własnej domeny wiedzy, które mogą przenieść na proces uczenia się uczniów oraz na tworzenie nowego, spójnego programu nauczania umiejętności informacyjnych, jak również na szerszą współpracę z wykładowcami (Association of College and Research Libraries, 2015).

$\mathrm{Na}$ fali powyższych refleksji ACRL w 2015 r. opublikowała nowe Ramy kompetencji informacyjnych dla szkolnictwa wyższego (Framework for Information Literacy for Higher Education). Opierają się one na koncepcji pojęć granicznych (threshold concepts). Opracowany dokument zawiera sześć pojęć granicznych związanych z kompetencjami informacyjnymi (Rozkosz, 2017: 73):

- wiarygodność i legitymizacja podmiotu jest konstruowana w kontekście (Authority is Constructed and Contextual) - zasoby informacyjne odzwierciedlają wiedzę i wiarygodność ich twórców, a także są oceniane na podstawie zapotrzebowania na informacje i kontekstu, w jakim informacje zostaną wykorzystane; 
- tworzenie informacji jako proces (Information Creation as a Process) informacje $\mathrm{w}$ dowolnym formacie są tworzone w celu przekazania wiadomości i są udostępniane za pośrednictwem wybranej metody dostarczania;

- informacja ma wartość (Information Has Value) - informacja ma kilka wymiarów wartości, w tym jako towar, jako środek edukacji, jako środek wywierania wpływu oraz jako środek do negocjowania i rozumienia świata. $\mathrm{Na}$ tworzenie i rozpowszechnianie informacji wpływają interesy prawne i społeczno-ekonomiczne;

- wyszukiwanie jako badanie (Research as Inquiry) - badania mają charakter iteracyjny i polegają na zadawaniu coraz bardziej złożonych lub nowych pytań, których odpowiedzi z kolei rozwijają dodatkowe pytania lub kierunki dociekań w dowolnej dziedzinie;

- nauka realizowana w rozmowie (Scholarship as Conversation) - społeczności uczących się, uczonych, badaczy lub profesjonalistów angażują się w trwały dyskurs z innymi w toku wymiany spostrzeżeń i odkryć pojawiających się $\mathrm{w}$ wyniku różnych perspektyw i interpretacji;

- szukanie jako strategiczne rozpoznawanie (Searching as Strategic Exploration) - poszukiwanie informacji jest często nieliniowe i iteracyjne, wymagające oceny szeregu źródeł informacji i elastyczności umysłowej, aby podążać alternatywnymi ścieżkami w miarę rozwoju nowego rozumienia (Association of College and Research Libraries, 2015).

W ramach wskazanych sześciu kategorii prezentowane są szczegółowe praktyki informacyjne oraz dyspozycje uczącego się. ACRL zaleca, aby ramy były wykorzystywane w sposób elastyczny, tj. aby nie traktować zestawu dyspozycji jako nowych standardów kompetencji do nauczenia.

Z uwagi na obfitość informacji we współczesnym świecie jednostki muszą legitymować się umiejętnością korzystania z informacji z silnym przekonaniem i wysokim poziomem pewności. Jest to związane z poczuciem własnej skuteczności w zakresie umiejętności korzystania z informacji, rozumianej jako zdolność i wiara jednostki w zdobywanie, ocenianie i wykorzystywanie informacji. Poczucie własnej skuteczności w zakresie umiejętności informacyjnych stanowi podstawę uczenia się przez całe życie, a dodatkowo ważne jest, aby zwiększać sukcesy uczniów. Dotyczy to wszystkich dyscyplin, niezależnie od poziomu edukacji i środowiska uczenia się. Im wyższy poziom poczucia własnej skuteczności w zakresie umiejętności informacyjnych, tym bardziej uczący się mogą stać się samodzielni i uzyskać lepszą kontrolę nad efektami uczenia się przez całe życie (Hee, Ping, Rizal, Tan, Fei, 2019). 


\section{Założenia badania}

Wskazane kategorie kompetencji w dokumencie Framework for Information Literacy for Higher Education stały się inspiracją i kanwą do przeprowadzenia wstępnych badań, których celem było poznanie procesu korzystania z informacji pozyskiwanych z przestrzeni Internetu $\mathrm{w}$ toku uczenia się w opinii studentów oraz w konsekwencji próba oceny wybranych aspektów kompetencji informacyjnych na podstawie użytkowania cyfrowej infosfery. $\mathrm{Z}$ tak postawionego celu badania wynikał problem badawczy w postaci pytania: $\mathrm{W}$ jaki sposób studenci wykorzystują Internet jako edukacyjne środowisko uczenia się?

Badanie zostało zrealizowane $\mathrm{z}$ wykorzystaniem metody sondażu diagnostycznego. Narzędziem badawczym był kwestionariusz ankiety „Internet w procesie studiowania", składający się z 18 pytań o charakterze zamkniętym i półotwartym, których treść koncentrowała się na:

- aktywności studentów w przestrzeni cyfrowej;

- źródłach informacji pozyskiwanych w procesie studiowania;

- umiejętności dokonywania oceny rzetelności i wiarygodności treści internetowych;

- wielostronnej ocenie korzyści, jak i trudności wynikających z korzystania ze źródeł internetowych.

Z uwagi na pilotażowy charakter badań kwestionariusz ankiety obejmował pytania na podstawie wybranych kategorii Ram Kompetencji Informacyjnych, prowadzące do uzyskania opinii studentów na temat procesu poszukiwania i pracy $\mathrm{z}$ informacjami. Sondaż przeprowadzono w semestrze zimowym w roku akademickim 2019/2020, uczestniczyło w nim 142 studentów I i II roku studiów stacjonarnych pierwszego stopnia na kierunku pedagogika.

\section{Wyniki badania}

Wstępnie starano się zorientować, które z urządzeń cyfrowych najczęściej posiadają badani na własność (wykres 1).

$\mathrm{Na}$ pierwszym miejscu znalazły się urządzenia mobilne - smartfon (głównie z systemem Android) i iPhone, które posiadają wszyscy badani (100\%). Na drugim laptop, zaś na trzecim miejscu pod względem popularności był komputer stacjonarny, traktowany jako sprzęt uniemożliwiający mobilne użytkowanie cyberprzestrzeni. Wyniki te wpisują się w obserwacje Zygmunta Baumana, który spostrzega, że „rewolucyjna zmiana $\mathrm{w}$ kondycji ludzkiej dokonała się $\mathrm{w}$ technologii informacyjnej w ciągu jednego pokolenia: począwszy od gigantycznych machin (...), a skończywszy na ty- 


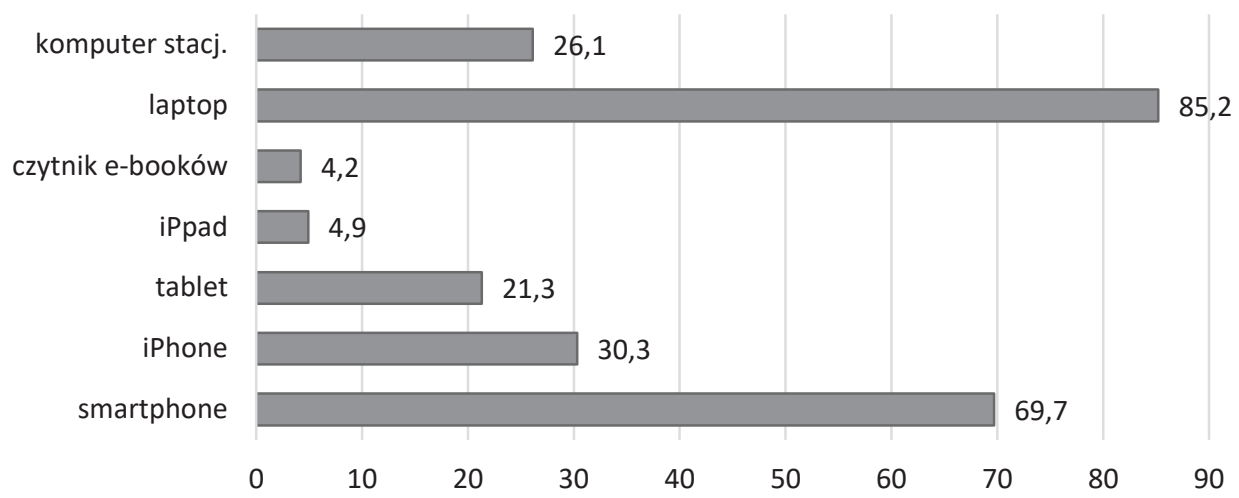

Wykres 1. Urządzenia technologii cyfrowych w posiadaniu studentów (\%)

Źródło: badania własne

siącach gadżetów, przenośnych komputerów, z czasem tak małych, że mieszczą się na dłoni (...), dostępnych dwadzieścia cztery godziny na dobę, siedem dni w tygodniu, dla miliardów posiadaczy i użytkowników w każdym wieku, trzymanych w kieszeni czy torbie, przez większość czasu jednak - w ręce" (Bauman, Leoncini, 2018: 77).

Główne i oczywiste powody tak dużego sukcesu smartfonów w świetle badań globalnych to poszerzenie ich funkcjonalności oraz znaczący rozwój dostępu do bezprzewodowego Internetu (zob. Majchrzyk, 2020). Studenci jako użytkownicy smartfonów są przyzwyczajeni do możliwości załatwienia wielu spraw codziennego życia w wolnym czasie i miejscu. Nie dziwią więc wyniki wskazujące, że studenci właśnie smartfon używają jako narzędzie najczęstszego łączenia się z globalną siecią $(95,1 \%)$. Zdecydowanie mniejszą popularnością cieszy się laptop, który do tego celu służy tylko prawie 39\% badanych (wykres 2).

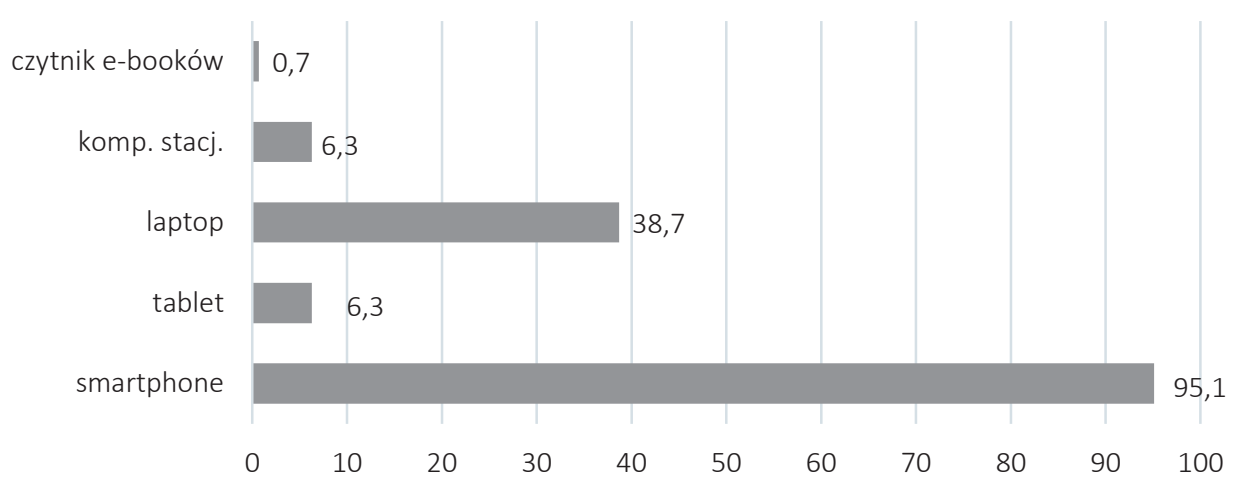

Wykres 2. Urządzenia wykorzystywane do łączenia się z Internetem (\%)

Źródło: badania własne 
W dobie powszechnej popularności Internetu i jego wielostronności sprawdziłam również, do jakich celów najczęściej wykorzystują go badani studenci (tab. 1).

Wśród możliwych wariantów korzystania z możliwości, jakie oferuje cyberprzestrzeń, poproszono studentów o ocenę zarówno tych powszechnie znanych i popularnych (związanych z komunikacją czy wyszukiwaniem informacji), jak i bardziej twórczych (dotyczących przetwarzania czy kreowania własnych treści cyfrowych). Wyniki badań wskazują, że największa liczba studentów wykorzystuje Internet $\mathrm{w}$ celu komunikowania się z innymi członkami swojej społeczności: rodziną, przyjaciółmi czy osobami z przestrzeni cyfrowej - wskazują na to wybory kategorii „zawsze” aż 81\% badanych. Równie powszechnym celem użytkowania wirtualnej przestrzeni są serwisy społecznościowe - 95,8\% respondentów także deklaruje, że będąc w sieci, zawsze i często są aktywni w social media. Media społecznościowe, umożliwiając jednoczenie wirtualnych społeczności digital natives, niezmiennie plasują się bardzo wysoko w rankingu popularności w przestrzeni cyfrowej. Każdy może mieć do nich dostęp i tym samym może uczestniczyć w ich tworzeniu, zaznaczając w nich swoją obecność, dzieląc się spostrzeżeniami i informacjami, czy kreując własny wizerunek i tożsamość.

Internet jest przestrzenią wykorzystywaną przez studentów do celów rozrywkowych - prawie $1 / 3$ z nich deklaruje, że zawsze słucha muzyki lub ogląda filmy w sieci (w połączeniu z kategorią "często" daje to blisko stuprocentowy odsetek badanych). Potwierdza to dominację ludyczności Internetu w użytkowaniu przez młode osoby zauważone $\mathrm{w}$ innych badaniach (Tanaś, Kamieniecki, Bochenek, Wrońska, Lange, Fila, Loba, Konopczyński, 2017).

Jak na tle tych najczęściej wybieranych aktywności lokuje się Internet jako źródło informacji $\mathrm{w}$ procesie studiowania? Wbrew oczekiwaniom okazało się, że "zawsze” informacje pozyskuje z sieci co piąty student, zaś połowa czyni to „często" (łączny odsetek studentów stanowi tu 3/4 ogółu). Uzyskany wynik może wskazywać, że Internet nie jest dla badanych najważniejszym źródłem treści wymaganych na studiach, a ich aktywność w sieci jest ukierunkowana na poszukiwania konkretnych, specjalistycznych informacji (wątek ten rozwijam w dalszej części tekstu).

Wśród najrzadziej lub nigdy niewybieranych aktywności w wirtualnej przestrzeni znalazły się tworzenie blogów (88,8\%), filmów (82,4\%) i grafiki $(57,8 \%)$. $\mathrm{Ta}$ - z założenia wstępna analiza - wskazuje na pewne deficyty związane z umiejętnością tworzenia treści cyfrowych i twórczego wykorzystywania nowych technologii. Wyniki wskazują, że większość studentów zajmuje się redystrybucją cyfrowych treści. Wpisują się one we wnioski formułowane przez autorów raportu Polskie badanie EU Kids Online 2018, gdzie stwierdzono, iż „adolescenci używają mediów 


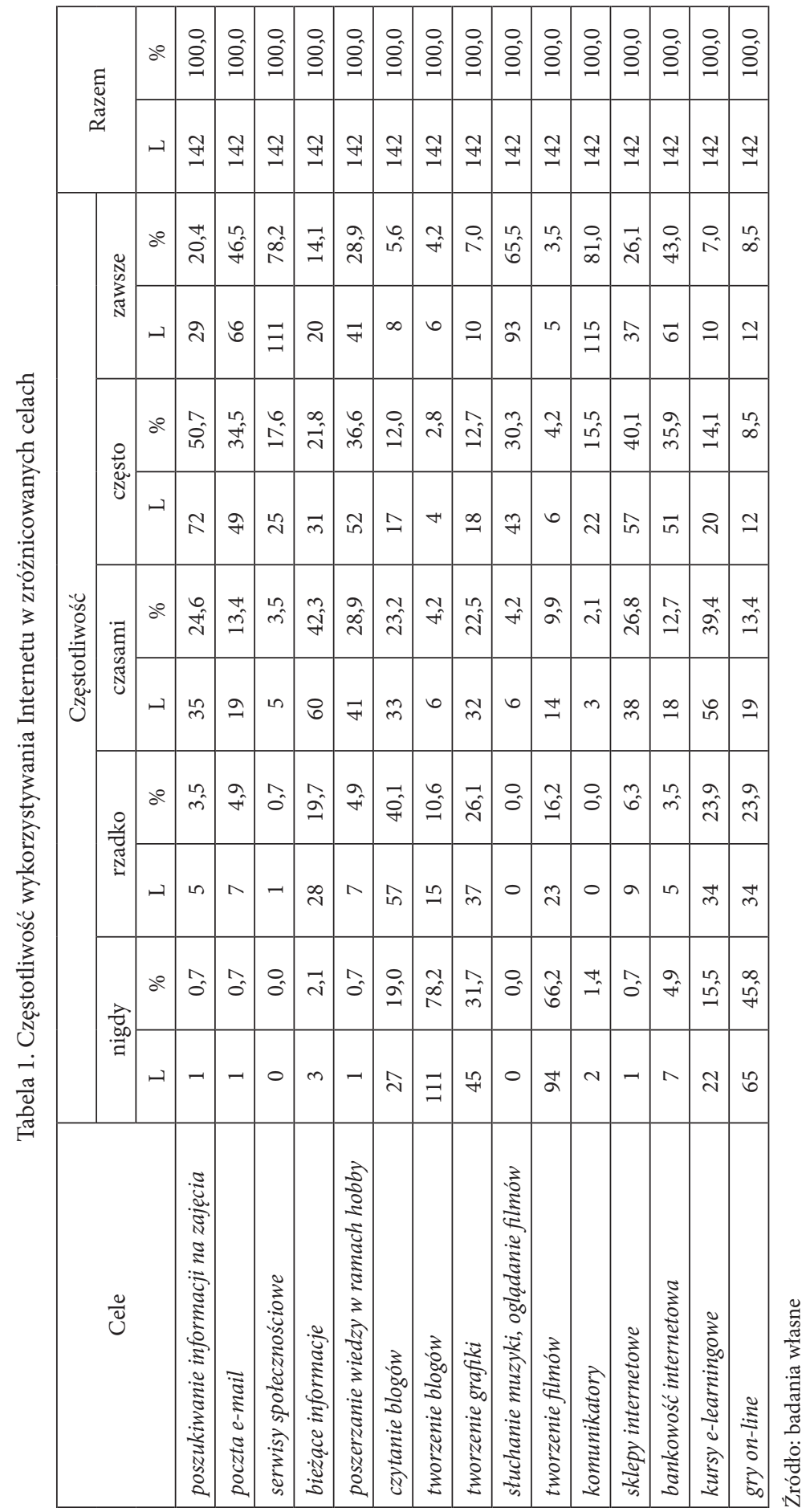


cyfrowych najczęściej w celach informacyjno-rozrywkowych. Młodzież jest zazwyczaj biernym odbiorcą informacji, a prawdziwie twórcze wykorzystanie tych informacji jest już zjawiskiem marginalnym" (Pyżalski, Zdrodowska, Tomczyk, Abramczuk, 2019: 157).

Wiedząc, że smartfon jest dla młodych ludzi przedmiotem o wyjątkowym znaczeniu, bez którego nie wyobrażają sobie wyjścia z domu i komunikacji z innymi, traktując go jak niezbędne narzędzie do nauki, życia, rozrywki - postanowiono sprawdzić stopień swoistego przywiązania do niego także w nocy (wykres 3).

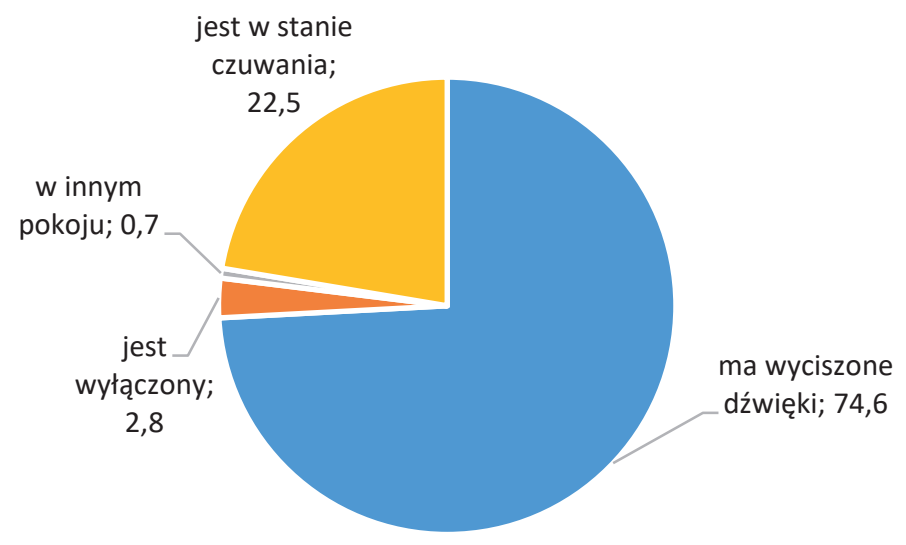

Wykres 3. Aktywność smartfona w nocy (\%)

Źródło: badania własne

Okazało się, że jedynie 3,5\% studentów potrafi rozstać się z telefonem w okresie snu (tylko nieliczni wyłączają go na noc lub zostawiają w innym pokoju). W stanie czuwania pozostawia smartfon blisko $1 / 4$ ankietowanych, co wpisuje się w opinię Lucyny Kopciewicz (2016: 533), iż „aktywność tych przedmiotów najlepiej oddaje termin «czuwanie» - one czuwają przy nas". Dla dzisiejszych studentów z pokolenia Z i młodszych z pokolenia Alfa technologia ta jest określana mianem przezroczystej. Smartfon stanowi jedno z pierwszych popularnych urządzeń zaprojektowanych tak, byśmy spędzali z nim czas. Manipulatorski charakter technologii smartfona dobrze oddają słowa jednego z menedżerów produktu w Google: „W latach siedemdziesiątych dwudziestego wieku za telefonem nie stało tysiąc inżynierów starających się przerobić go tak... by był coraz bardziej przekonywujący" (za: Price, 2018: 31).

Celem kolejnego pytania było sprawdzenie, w jakim momencie dnia/doby studenci zaczynają surfować w cyberprzestrzeni (wykres 4). Nie jest zaskoczeniem, 
że dla blisko połowy badanych jest to pierwsza czynność po obudzeniu się (49\%) lub podczas śniadania (21\%). Internet towarzyszy młodym ludziom także w nocy, gdyż 15,5\% z nich zajmuje się wędrówką po wirtualnej przestrzeni w czasie przeznaczonym teoretycznie na sen i odpoczynek.

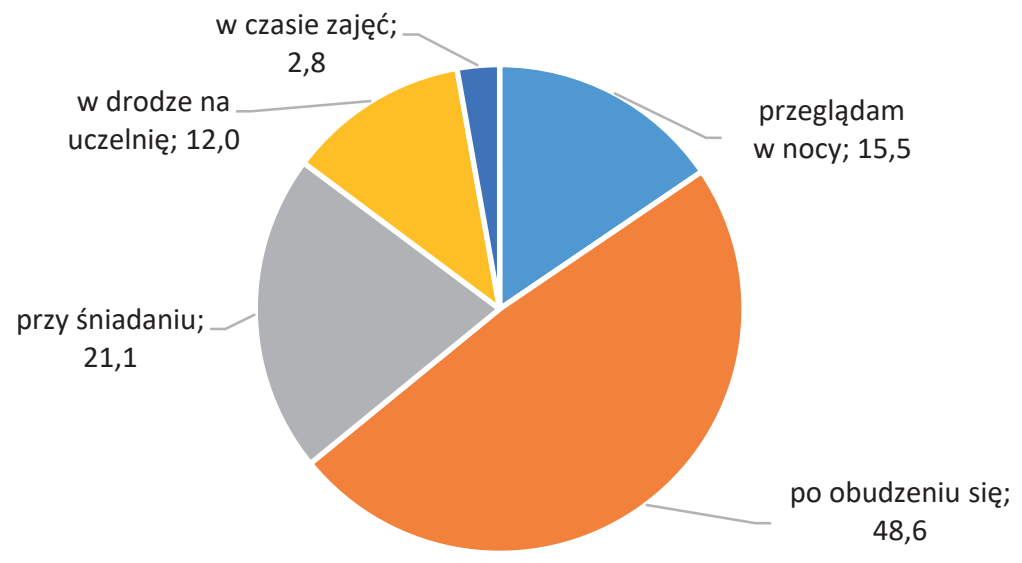

Wykres 4. Pierwszy kontakt z Internetem w ciągu doby (\%)

Źródło: badania własne

Anders Hansen, szwedzki psychiatra i badacz Internetu uświadamia, że komórkę dotykamy ponad 2600 razy dziennie i bierzemy do ręki przeciętnie co 10 minut - w okresie czuwania, zaś jedna na trzy osoby (co stanowi 50\% wszystkich z grupy wiekowej 18-24) sprawdza smartfon co najmniej raz w ciągu nocy (Hansen, 2020: 59). Można założyć, że telefon komórkowy jest nie tylko dla studentów ostatnim przedmiotem, który widzą przed snem i pierwszym tuż po obudzeniu się. Zdecydowana mniejszość ankietowanych potrafi obejść się bez sieci w początkowym momencie dnia - jedynie 14,8\% korzysta $\mathrm{z}$ Internetu znacznie później - w drodze na uczelnię lub w trakcie zajęć.

$\mathrm{W}$ murach uczelni kontakt $\mathrm{z}$ Internetem deklaruje wielu studentów, co nie powinno dziwić (wykres 5), gdyż przynależą do pokolenia - określanego przez Jean M. Twenge (2019) - iGen. Najstarsi przedstawiciele iGenu wchodzili w okres nastoletni w 2007 r. (wprowadzenie na rynek iPhone’a), w roku 2010 (pojawienie się iPada) byli już w liceum. IGen jest pierwszym pokoleniem, mającym nieograniczony dostęp do Internetu, zaś obserwacje cytowanej autorki potwierdzają powszechnie znaną tendencję do całkowitej dominacji smartfonów, odbijającej się w każdej sferze życia młodych - włączając interakcje społeczne oraz zdrowie psychiczne (Twenge, 2019). 


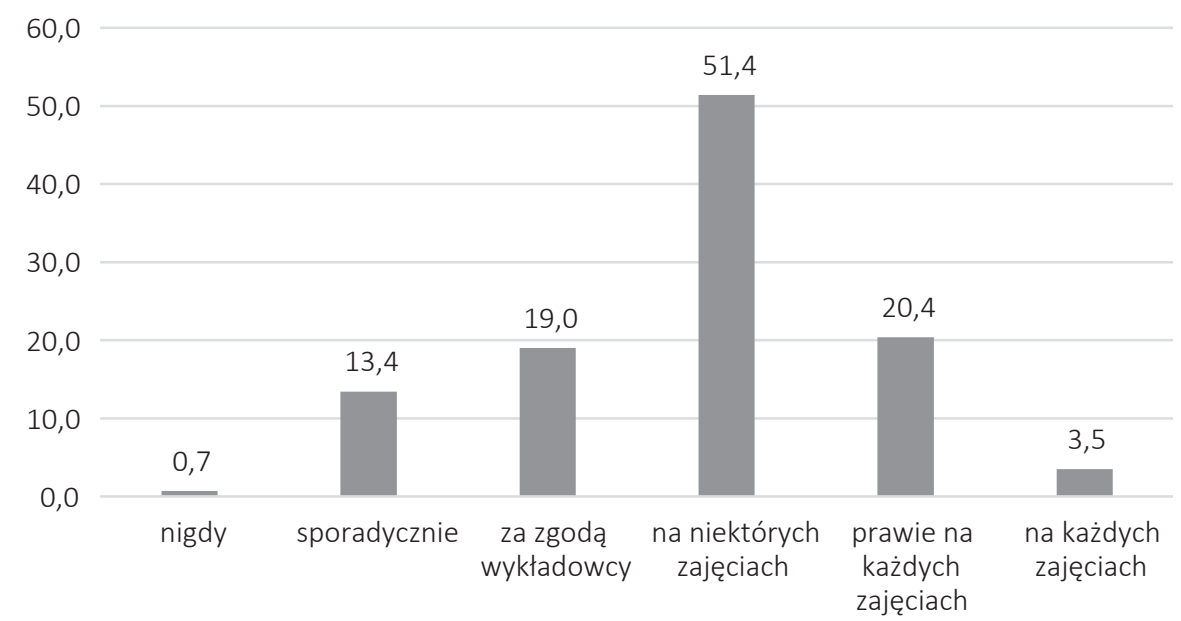

Wykres 5. Sytuacje korzystania z Internetu podczas zajęć na uczelni w celu dostępu do materiałów (\%) Źródło: badania własne

Na niektórych zajęciach korzysta z sieci połowa badanych, zaś $20 \%$ z nich łączy się z siecią prawie na każdych zajęciach. Podobna liczba młodych ludzi czyni to jedynie za zgodą prowadzących, co wskazuje na pewne obostrzenia w wykorzystywaniu prywatnych urządzeń mobilnych na zajęciach. Smartfony są współcześnie doskonałym narzędziem służącym rozrywce, budowaniu relacji, poszukiwaniu wzorców społecznych, ale także umożliwiają zdobywanie informacji i pogłębianie własnej wiedzy. Umożliwienie wykorzystania smartfona do codziennej edukacji akademickiej można uznać za naturalne przedłużenie ich codziennej cyfrowej aktywności. Osobiste smartfony studentów wykorzystywane w celach edukacyjnych w wielu sytuacjach dydaktycznych stają się kluczem do ich aktywizacji w zakresie realizacji treści przedmiotów objętych programem studiów. Umożliwić to może akceptacja osób prowadzących zajęcia oraz wdrożenie modelu BYOD (Bring Your Own Device - przynieś swoje urządzenie), szeroko omawiane w literaturze przedmiotu (zob. m.in. Song, Kong, 2017; French, Guo i Shim, 2014; Afreen, 2014).

Dalsza część analizy wyników badań dotyczyć będzie okoliczności wykorzystywania Internetu przez studentów w procesie studiowania. Na wstępie poproszono badanych o wskazanie najbardziej popularnych źródeł informacji w trakcie przygotowywania się do zajęć (wykres 6).

Czołowe miejsce $\mathrm{w}$ rankingu zajmuje Internet, na który wskazało prawie 3/4 badanych (72\%). Nie jest to wynik, który zaskakuje, tym bardziej, że nie ma przeszkód, by zasoby Internetu wykorzystywać w procesie edukacji, tak jak wszelkie tradycyjne środki dydaktyczne i źródła informacji. Należy tutaj zaznaczyć, iż 
niektórzy studenci proszeni o komentarz jakościowy uzupełniający wybraną przez siebie kategorię wskazywali, że niektórzy wykładowcy w zdecydowany sposób przeciwstawiali się korzystaniu z Internetu jako źródła informacji, optując wyłącznie za źródłami tradycyjnymi. W dyskusji dotyczącej wartości tych diametralnie odmiennych nośników treści (tekst tradycyjny vs. tekst cyfrowy) należy zaakcentować, że najistotniejszy jest proces przetwarzania informacji zachodzący w umyśle użytkownika - pozostawienie informacji jedynie na papierowym lub cyfrowym nośniku nie przyczyni się do procesu rozbudowywania własnej wiedzy.

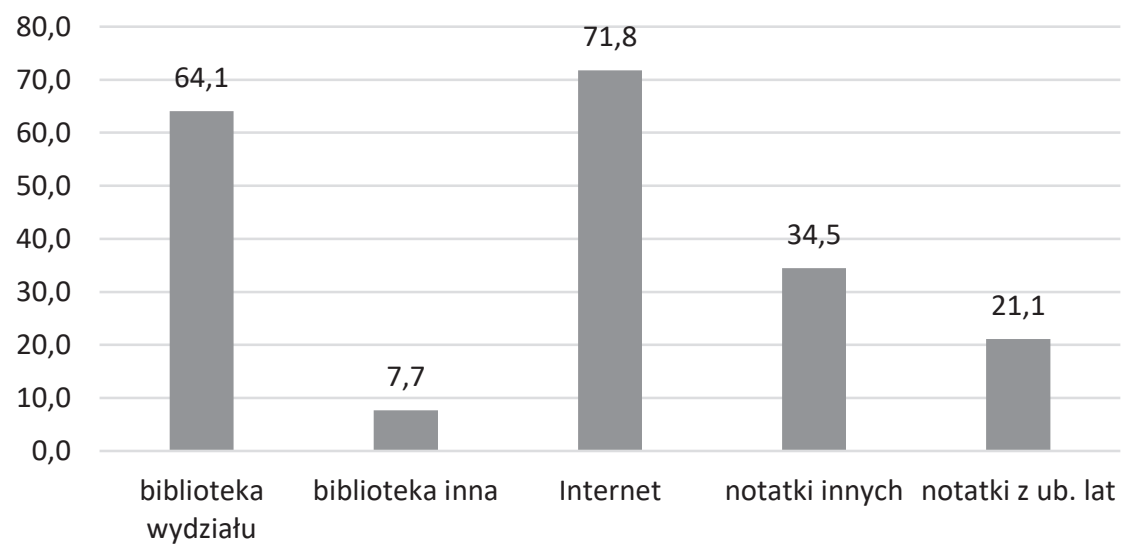

Wykres 6. Źródła informacji służące przygotowywaniu się do zajęć (\%)

Źródło: badania własne

Duża część ankietowanych studentów chętnie korzysta z tradycyjnych (wskazywanych w uzupełniających odpowiedziach jakościowych jako priorytetowe w opinii wykładowców) źródeł informacji znajdujących się w bibliotece, tak wydziałowej, jak i pozauczelnianej (72\%). Połowa studentów preferuje sposób pozyskiwania treści edukacyjnych zdecydowanie niewymagający dużego wysiłku intelektualnego, jakim są notatki studiujących znajomych z roku lub notatki z lat ubiegłych (55,6\%).

W obliczu wysokiego odsetka osób traktujących Internet jako ważne źródło treści, uzupełnieniem było pytanie o częstotliwość korzystania z niego. Z cyfrowych zasobów sieci często korzysta $61 \%$ studiujących, zaś $16 \%$ z nich deklaruje, że jest to permanentne źródło informacji w procesie uczenia się (wykres 7). Od czasu do czasu do internetowych zasobów sięga co piąty badany (blisko 20\%). Uogólniając, zauważa się, że co trzeci student nie wyobraża sobie procesu poszukiwania treści edukacyjnych bez Internetu. 


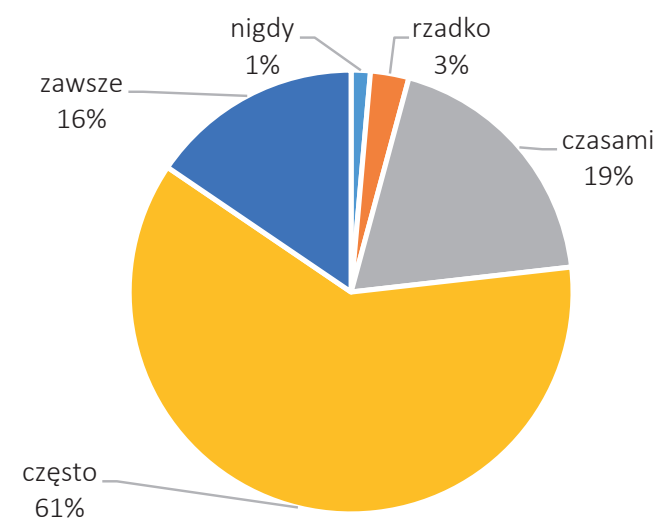

Wykres 7. Częstotliwość korzystania z Internetu jako źródła informacji w procesie studiowania (\%) Źródło: badania własne

Taka sytuacja nie zaskakuje, jednak warunkiem wartościowego użytkowania cyfrowych zasobów są rozwinięte kompetencje krytyczne. W przeciwnym wypadku, co podkreśla Ryszard Tadeusiewicz (1989: 10), „jeśli użytkownik ma zbyt mało własnej wiedzy i wynikającego z jej posiadania zdrowego krytycyzmu - może łatwo wziąć pozór prawdy za prawdę jako taką, co w sensie teorii informacji jest równoważne «pozyskaniu» informacji ujemnej (docelowa entropia systemu wzrasta)".

Deklaracje badanych wskazują, że najczęstszym materiałem pozyskiwanym $\mathrm{z}$ sieci są książki w formacie pdf (korzystają z nich prawie wszyscy badani) oraz artykuły naukowe - wybór 64,1\% badanych (wykres 8). W kontekście zagrożenia pozyskiwania „ujemnych informacji” wydaje się, że selekcja treści pod względem kryterium naukowości takie zagrożenie wyklucza. Poza sferą badania pozostawiono pytanie o legalność pozyskiwanych materiałów. Można przypuszczać, że spora część publikacji jest ulokowana w sieci zgodnie z prawami autorskimi (np. zgodnie z zasadami licencji Creative Commons), jednakże należy także założyć, że dalsze wykorzystywanie pozyskanych publikacji może mieć charakter sprzeczny z zasadami własności intelektualnej (np. brak cytowań, odniesień do autora i źródła). Należy także zwrócić w tym miejscu uwagę na liczne odpowiedzi wskazujące na strony odsyłające do rzetelnych publikacji naukowych (np. Google Scholar, ResearchGate czy repozytoria uczelni wyższych oraz wydawnictw naukowych). Te ostatnie opinie mogą świadczyć o dobrze rozwiniętej umiejętności oceny źródeł informacji, jak również legitymowaniu się znajomością zagadnień etycznych i prawnych związanych z korzystaniem z cudzej własności intelektualnej. 


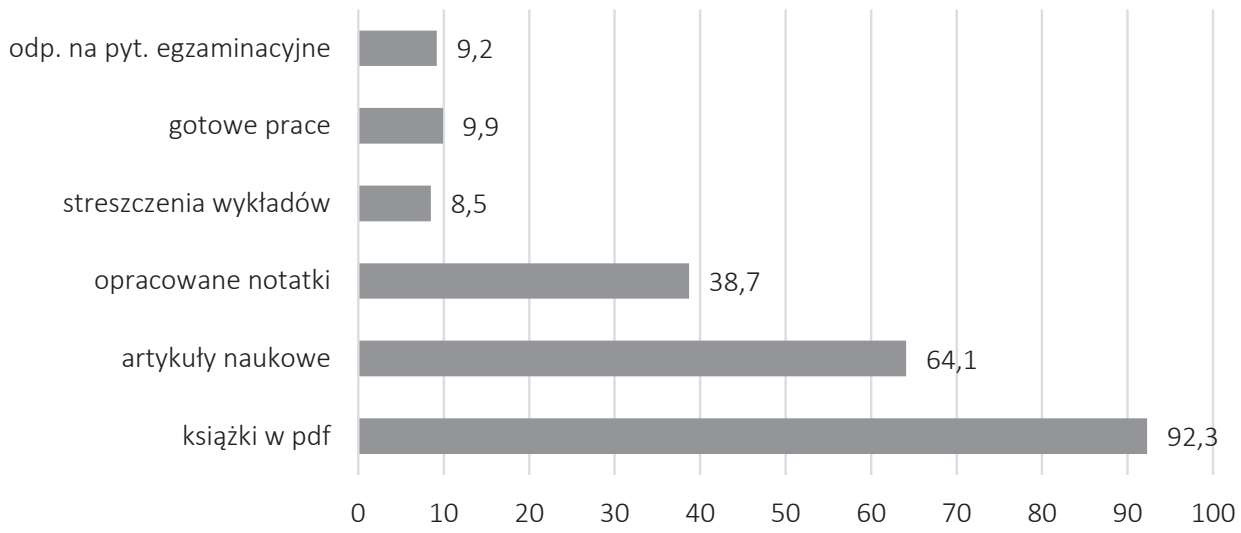

Wykres 8. Rodzaje materiałów wykorzystywanych przez studentów w Internecie (\%)

Źródło: badania własne

Z drugiej zaś strony zastanawia postawa blisko 40\% studentów eksplorujących zasoby Internetu w poszukiwaniu gotowych opracowań. Nie napawa optymizmem fakt, że ponad $66 \%$ badanych promuję kulturę nieuczciwości studenckiej. Beata Bielska opisuje ją jako „utrwalone i przekazywane wartości, normy, postawy i wzory zachowań studentów wiążące się ze stałym, powszechnym przyzwoleniem na łamanie norm oficjalnych dotyczących pełnienia roli społecznej studenta" (Bielska, 2015: 19). Grupa ta eksploruje informacyjne zasoby Internetu w poszukiwaniu gotowych materiałów wymaganych na zajęcia lub ułatwiających uzyskanie zaliczenia czy egzaminu (gotowe prace, opracowane notatki, odpowiedzi na pytania egzaminacyjne czy streszczenia wykładów). Badani poproszeni o wskazanie przykładowych stron, z których korzystają, podawali: ściąga.pl, docer, notatek.pl i inne serwisy społecznościowe utworzone w celu wymiany gotowych materiałów edukacyjnych.

Celem badania było także sprawdzenie, $\mathrm{w}$ jakim stopniu studenci oceniają korzyści wynikające z korzystania z treści internetowych (tabela 2). Największy odsetek badanych, bo ponad $60 \%$ przyznał, że największą korzyścią jest możliwość stałego dostępu do zasobów cyfrowych. Ułatwiony dostęp do informacji zawartych w Internecie może dawać studentom złudne przeświadczenie, że pamiętają więcej, mogąc $\mathrm{w}$ dowolnym momencie powrócić do przeszukiwanych treści. Analizy wskazują, że traktowanie Internetu jako zewnętrznych zasobów naszej pamięci powoduje, że w dłuższej perspektywie tracimy zdolność magazynowania informacji w naszych własnych mózgach. Pojawienie się Internetu osłabiło potrzebę zapamiętywania informacji ważnych z punku widzenia jednostki, co Daniel Wegner określa zjawiskiem efektu Google (Sparrow, Liu, Wegner, 2011). 
Tabela 2. Ocena stopnia korzyści wynikających z korzystania z treści internetowych

\begin{tabular}{|c|c|c|c|c|c|c|c|c|c|c|c|c|}
\hline \multirow{3}{*}{$\begin{array}{l}\text { Rodzaje } \\
\text { korzyści }\end{array}$} & \multicolumn{10}{|c|}{ Stopień korzyści } & \multirow{2}{*}{\multicolumn{2}{|c|}{ Razem }} \\
\hline & \multicolumn{2}{|c|}{ brak } & \multicolumn{2}{|c|}{$\begin{array}{c}\text { bardzo } \\
\text { mała }\end{array}$} & \multicolumn{2}{|c|}{$\begin{array}{l}\text { umiarko- } \\
\text { wana }\end{array}$} & \multicolumn{2}{|c|}{ duża } & \multicolumn{2}{|c|}{ bardzo duża } & & \\
\hline & $\mathrm{L}$ & $\%$ & $\mathrm{~L}$ & $\%$ & $\mathrm{~L}$ & $\%$ & $\mathrm{~L}$ & $\%$ & $\mathrm{~L}$ & $\%$ & $\mathrm{~L}$ & $\%$ \\
\hline $\begin{array}{l}\text { oszczędność } \\
\text { czasu }\end{array}$ & 0 & 0,0 & 5 & 3,5 & 24 & 16,9 & 58 & 40,8 & 55 & 38,7 & 142 & 100,0 \\
\hline $\begin{array}{l}\text { informacje } \\
\text { rzetelne }\end{array}$ & 2 & 1,4 & 32 & 22,5 & 70 & 49,3 & 31 & 21,8 & 7 & 4,9 & 142 & 100,0 \\
\hline $\begin{array}{l}\text { informacje } \\
\text { najważniej- } \\
\text { sze }\end{array}$ & 2 & 1,4 & 20 & 14,1 & 55 & 38,7 & 48 & 33,8 & 17 & 12,0 & 142 & 100,0 \\
\hline stały dostęp & 2 & 1,4 & 2 & 1,4 & 9 & 6,3 & 35 & 24,6 & 94 & 66,2 & 142 & 100,0 \\
\hline $\begin{array}{l}\text { brak ko- } \\
\text { nieczności } \\
\text { robienia } \\
\text { odręcznych } \\
\text { notatek }\end{array}$ & 6 & 4,2 & 13 & 9,2 & 35 & 24,6 & 39 & 27,5 & 49 & 34,5 & 142 & 100,0 \\
\hline $\begin{array}{l}\text { maly nakład } \\
\text { pracy }\end{array}$ & 7 & 4,9 & 27 & 19,0 & 54 & 38,0 & 33 & 23,2 & 21 & 14,8 & 142 & 100,0 \\
\hline
\end{tabular}

Źródło: badania własne

Skutki przyspieszenia tempa życia wywołanego gwałtownym rozwojem technologicznym zauważyć można w opiniach prawie $80 \%$ studentów, którzy uznali oszczędność czasu za znaczący pozytyw internetowej aktywności w procesie studiowania. Ciekawym wynikiem są oceny prawie $60 \%$ badanych, którzy z zadowoleniem przyjmują zwolnienie z konieczności ręcznego tworzenia notatek jako konsekwencję wykorzystywania informacji internetowych. Stoi to w korelacji z opiniami 38\% badanych, którzy uznali, że korzystanie z Internetu skutkuje małym nakładem pracy. Niestety, tendencja ta wpisuje się w zjawisko określane przez Umberto Eco jako kserokultura: „neuroza fotokopii (...) często stanowi także intelektualne alibi; ten bowiem, kto wychodzi z biblioteki obarczony plikiem fotokopii, ma zwykle pewność, że nigdy nie zdoła ich wszystkich przeczytać, nie będzie nawet w stanie ich odnaleźć, gdyż już teraz panuje w nich bałagan, ale jednocześnie ma poczucie, że zawładnął treścią ksiąg" (Eco, 2007: 28).

Ocena Internetu jako źródła rzetelnych informacji w opinii badanych kształtuje się natomiast ambiwalentnie $-z$ jednej strony $23,9 \%$ wskazuje na ostrożność, ale z drugiej - podobna liczba studentów postrzega rzetelność zasobów cyfrowych jako dużą korzyść $(26,7 \%)$. 
Globalna sieć internetowa jest narzędziem dającym, z jednej strony, nieograniczone możliwości wymiany i pozyskiwania informacji, a z drugiej to miejsce, w którym ich nadmiar stwarza zagrożenia pojawiania się informacji niesprawdzonych lub nieprawdziwych. Pocieszające jest, że w ocenie połowy badanej młodzieży Internet jako źródło informacji okazuje się mało przydatny, a więc niewystarczający (niski poziom wiarygodności), a 38\% z nich wystawia mu zaledwie przeciętną ocenę (wykres 9).

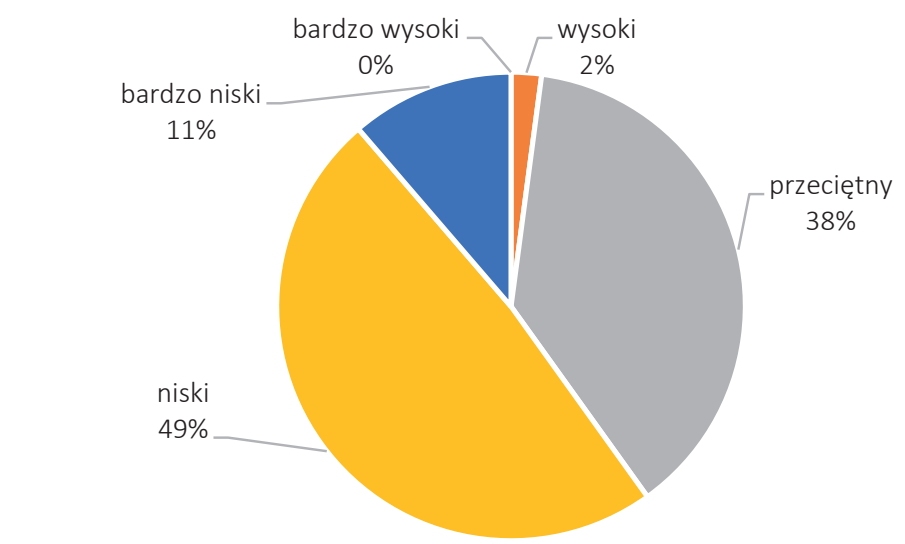

Wykres 9. Ocena stopnia przydatności informacji zawartych w Internecie (\%)

Źródło: badania własne

Takie oceny wskazują na rozwiniętą u studentów wrażliwość informacyjną i mimo chętnego sięgania po łatwo dostępne informacje przejawiają także postawę ostrożnego poszukiwacza i krytycznego odbiorcy treści zamieszczanych w sieci. Steven Poole, brytyjski publicysta i pisarz badający media, kulturę współczesną, zmiany językowe i mowę Internetu, zauważa, że w „zachłyśnięciu (...) informacyjną płodnością uwierzyliśmy, że Big Data jest cudownym lekiem na bolączki świata. Tymczasem to nie informacja naprawia świat, lecz wiedza, która bierze się Z właściwej interpretacji tej informacji” (Siewiorek, 2014: 27).

Opinie sporej grupy badanych o niskiej przydatności materiałów informacyjnych znajdowanych w sieci stoją w korelacji z kolejnym aspektem wyników sondażu, tj. częstotliwością sprawdzania wiarygodności materiałów znalezionych w sieci (wykres 10).

Okazuje się, że większość studentów czyni to często (41\%) i zawsze (20\%), a jedynie znikomy odsetek (5\%) przyznaje, że rzadko podejmuje taki trud. Świadczy to pozytywnie o kompetencjach informacyjnych młodych dorosłych, przejawiających taki krytyczny ogląd cyfrowych treści. 


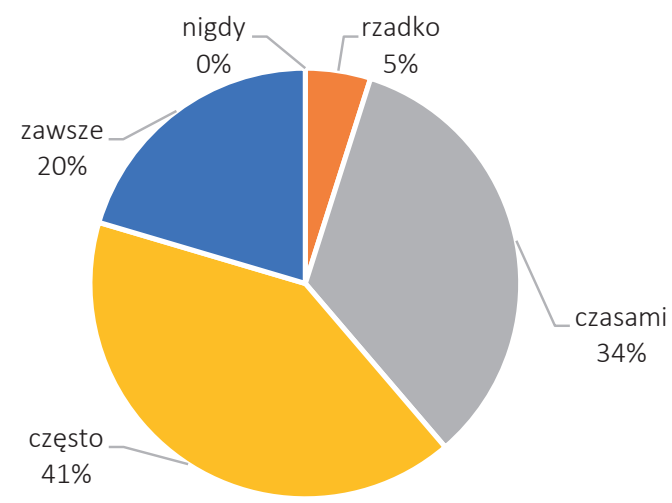

Wykres 10. Częstotliwość sprawdzania wiarygodności materiałów znalezionych w sieci (\%)

Źródło: badania własne

W odpowiedzi na pytanie o sposoby sprawdzania prawdziwości informacji pochodzących z Internetu największa liczba studentów porównuje je z tradycyjnymi źródłami papierowymi (książka, artykuł) - tak zachowuje się 3/4 badanych (wykres 11).

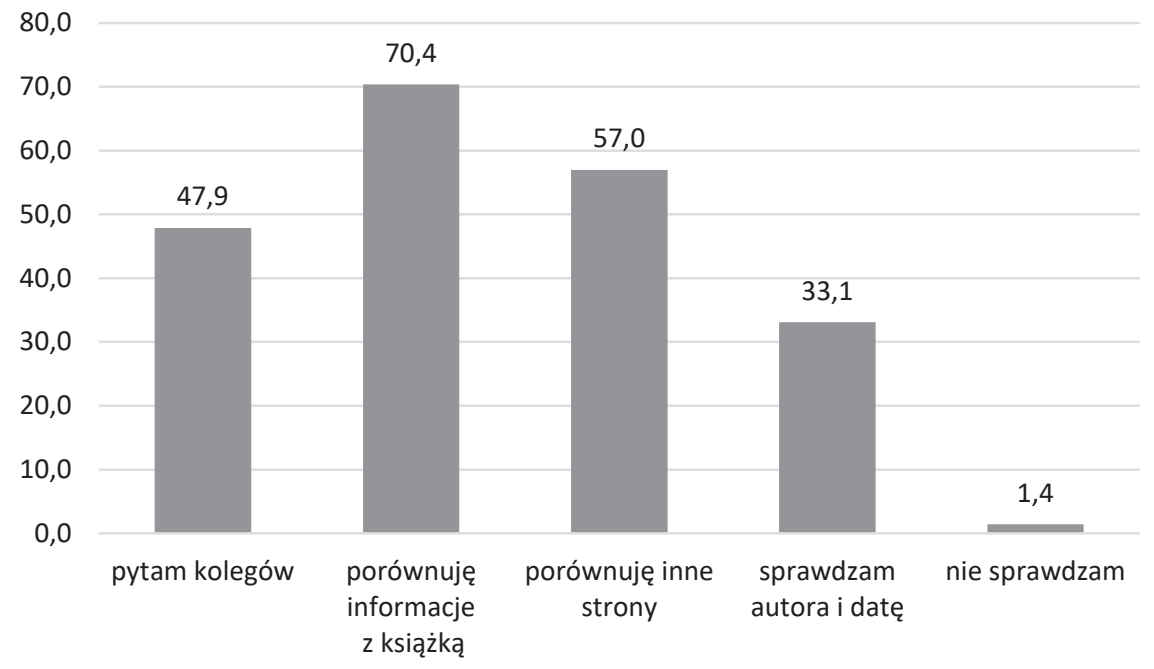

Wykres 11. Sposób sprawdzania rzetelności informacji z Internetu (\%)

Źródło: badania własne

Chętnie wykorzystywaną metodą oceny wiarygodności treści cyfrowych jest rozmowa $\mathrm{z}$ innymi studiującymi z roku (48\%) i porównywanie zawartości innych stron internetowych (57\%). Można przypuszczać, że w powyższym przypadku ocenie podlega przede wszystkim treść. Oceniając informacje internetowe, powinno się także 
zwrócić uwagę na inne kryteria, jak kompletność, obiektywność czy autorytet autora i aktualność danych. Te ostatnie kryteria bierze pod uwage 33\% studentów, którzy sprawdzają autora i datę aktualizacji strony internetowej. Można uznać, że jest to dobry prognostyk kompetencji informacyjnych, których przejawem powinna być umiejętność krytycznej analizy treści, nawyk sprawdzania źródeł czy ogólne zorientowanie w naturze współczesnych mediów masowych. W opinii autorów raportu Bezpieczne wybory. Badanie opinii o (dez)informacji w sieci „są kluczowe w ocenie podatności społeczeństw na dezinformację i manipulację w sieci” (Bochenek, Lange, 2019: 16).

Interesującym wydało się także sprawdzenie przyczyn poszukiwania informacji poza Internetem (wykres 12).

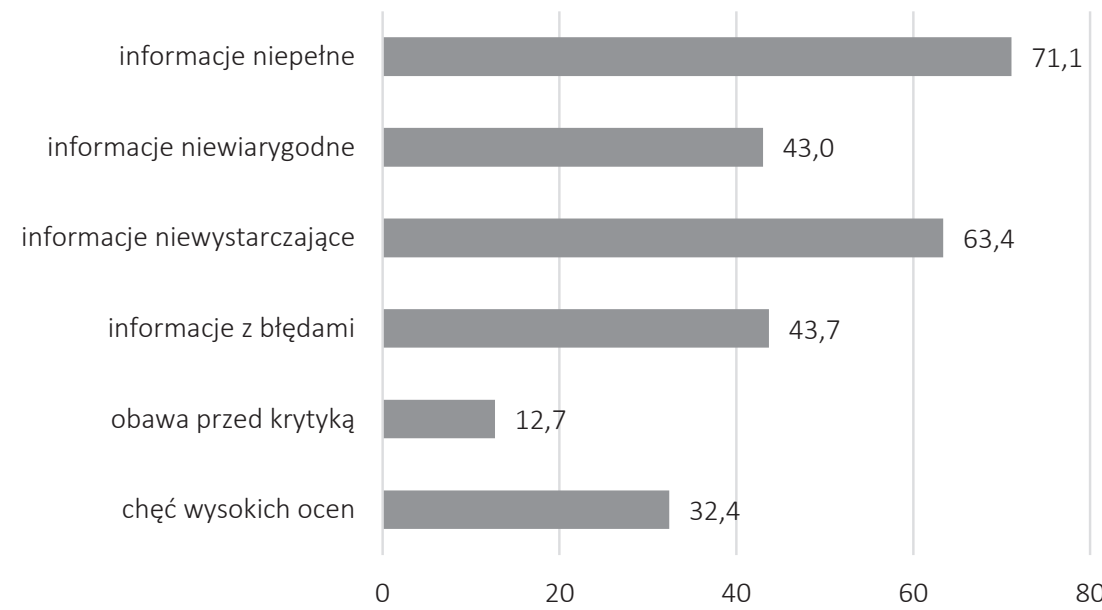

Wykres 12. Przyczyny szukania informacji poza Internetem (\%)

Źródło: badania własne

Największy odsetek studentów wskazał, że główną przyczyną jest niedokładność (niepełność) informacji znajdowanych w sieci $(71,1 \%)$ oraz ich niewystarczająco wysoka jakość w uzyskaniu wysokich efektów uczenia się $(63,4 \%)$. Podobna liczba ankietowanych uznała, że w Internecie można często napotkać informacje o małym stopniu wiarygodności czy wręcz z błędami (około 43\%). Najmniej studentów deklaruje, że przyczyną korzystania z informacji tradycyjnych jest uniknięcie krytyki wykładowców (13\%), co może sugerować, że prowadzący zajęcia nie zawsze akceptują praktykowanie pozyskiwania informacji z sieci, niezależnie od ich jakości merytorycznej.

W tej perspektywie opanowanie umiejętności wyszukiwania i krytycznej selekcji potrzebnych informacji, wypracowanie umiejętności ich przetwarzania w celu roz- 
wiązania problemu staje się nadrzędną kompetencją poznawczą wymaganą w procesie samodzielnego uczenia się $\mathrm{w}$ erze cyfrowej.

W opozycji do korzyści wynikających z korzystania z cyfrowych treści interesujące są deklaracje studentów dotyczące negatywnych aspektów ich użytkowania (wykres 13). W opinii 68\% studentów największą przeszkodą jest możliwość napotkania błędów i niska rzetelność (45\%). Badani przyznają także, że borykają się z trudnościami wyboru istotnych informacji (43\%), co potwierdzają opinie blisko $1 / 3$ z nich, że doświadczają natłoku informacyjnego.

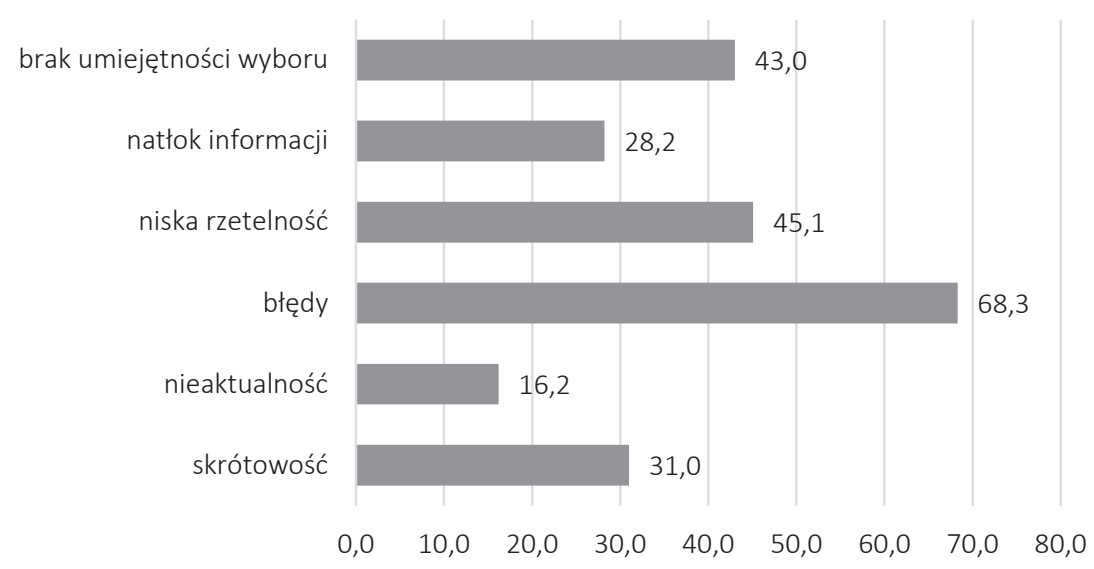

Wykres 13. Negatywne aspekty wykorzystywania Internetu jako źródła informacji (\%)

Źródło: badania własne

Tak wysoki odsetek studentów podzielających taki osąd potwierdza doniesienia $\mathrm{z}$ wielu innych badań, wskazujących na problem przeładowania informacyjnego oraz konsekwencji psychologicznych związanych z nadmiarem treści (por. Ledzińska 2009, 2012; Babik 2010; Gleick, 2012). Jako skutek nadmiaru informacji pojawia się obciążenie uwagi i pamięci, w efekcie osłabienie lub utrata kontroli poznawczej. Odbiór, selekcja i przetwarzane umysłowe informacji w sytuacji ich nadmiaru stają się więc znacząco utrudnione.

\section{Wnioski}

Analiza wyników badań pozwala na sformułowanie pewnych wniosków, które mogą służyć jako wyznacznik dyrektyw praktycznych w procesie doskonalenia edukacji informacyjnej i medialnej na poziomie kształcenia wyższego. Studenci 
w przeważającej większości bazują na informacjach znalezionych w Internecie, ale wskazują także biblioteki jako ważne miejsca poszukiwania treści niezbędnych w procesie studiowania (co jest budujące). Główne powody korzystania z Internetu to oszczędność czasu, stawiane na równi z jego brakiem oraz traktowanie cyfrowych zasobów sieci jako najszybszego i najłatwiejszego źródła pozyskiwania treści, dostępnego 24 godziny na dobę, $7 \mathrm{dni}$ w tygodniu. Mimo tak postrzeganych korzyści i niewyobrażania sobie funkcjonowania bez Internetu przejawiają także postawę dość krytyczną w ocenie rzetelności informacji pozyskiwanych z sieci, oceniając stopnień przydatności jako niski. W konsekwencji badani studenci często sprawdzają informacje znalezione w sieci, a najczęściej wykorzystywanym kryterium weryfikacji jest dyskusja z innymi, porównywanie treści cyfrowych z książkami i innymi stronami internetowymi o podobnej treści.

Wydaje się zasadne, aby wybrane aspekty kompetencji informacyjnych studentów (krytycyzm w odbiorze treści i nieufność wobec zasobów sieci) wzmacniać konkretnymi działaniami z zakresu edukacji informacyjnej. Jednym z nich jest przeciwdziałanie pobieraniu i magazynowaniu wielu niepotrzebnych danych przy jednoczesnym odraczaniu (lub braku) ich selekcjonowania, przetwarzania i tworzenia syntez. Ważnym jest także uświadamianie konsekwencji poznawczych wynikających ze spłyconego procesu operowania informacjami oraz wzmacnianie myślenia krytycznego w kontekście selekcji, wyboru i przetwarzania informacji. Współcześnie korzystanie z mediów oferujących informacyjne bogactwo to nie tylko umiejętności techniczne obsługi wielorakich aplikacji cyfrowych, to także znajomość mechanizmów kulturowych rządzących mediami i - może przede wszystkim - zdolność tworzenia własnych treści, zdolność pozyskiwania informacji, ich przetwarzania i uczestnictwa w sieciowych społecznościach informacji i wiedzy. Moim zdaniem - na takie właśnie cele - powinno być ukierunkowane wykorzystanie technologii informacyjnych przez studentów w edukacji akademickiej.

\section{Zakończenie}

Wyszukiwanie informacji w Internecie - dziś traktowane jako czynność powszednia, automatyczna i niejako naturalna - nie zawsze było postrzegane $\mathrm{w}$ taki sposób. Z historii korporacji Google można dowiedzieć się, że jej założyciele Larry Page i Sergey Brin, szukając kupca na wymyśloną przez siebie technologię, otrzymali krótki przekaz od jednego z dyrektorów portali, iż „naszych użytkowników nie obchodzi wyszukiwanie” (Halavais, 2012: 73). Komentarz tej treści 
wydaje się dziś całkowicie niezrozumiały, gdyż dynamiczny rozwój technologii informacyjnych i algorytmów wyszukiwania informacji sprawiły, że każdy z nas odruchowo kieruje swoje kroki w procesie rozwiązywania problemów informacyjnych do przestrzeni Internetu. Na przestrzeni ostatnich dziesięcioleci zmienił się diametralnie nasz stosunek do wyszukiwania informacji, co podkreśla Alexander Halavais (2012: 73): „kiedy zmienia się podstawowy sposób, w jaki poruszamy się po świecie nowych treści, można zakładać, że zmiany te przenikną do innych aspektów naszej kultury”. Niesłychanie uproszczony dostęp do wyszukiwarek i przeświadczenie wielu o „łatwym” procesie wyszukania informacji skutkuje ignorowaniem wcześniejszych, „przedinternetowych” sposobów kategoryzowania i selekcjonowania określonych treści. Argument ten przemawia za koniecznością kształcenia i stymulowania kompetencji informacyjnych człowieka, które - wraz ze zmianami cywilizacji informacyjnej - także ulegają przekształceniom i ewoluują.

Perspektywa ta pozwala zauważyć, że z funkcjonowaniem pokolenia cyfrowego łączy się powszechne, ale często błędne przekonanie o ich nadzwyczajnych, wrodzonych kompetencjach cyfrowych i związanych z nimi wysoko ukształtowanych umiejętnościach wyszukiwania informacji. Jak zauważa Halavais (2012: 54) w swojej ocenie procesu użytkowania internetowych wyszukiwarek: „mimo, że młodzi ludzie mogą nie pamiętać czasów, gdy wyszukiwarki nie istniały, nie oznacza to jednak, że są oni mistrzami w korzystaniu z nich. Pewne czynności, które wielu z nas wykonuje obecnie bez zastanowienia, musiały być kiedyś przedmiotem nauki, a ponieważ są to zachowania silnie zakorzenione w naszych umysłach, zapominamy, że nie należą do zestawu umiejętności przeciętnego wyszukującego".

Studenci jako grupa społeczna równolegle żyjąca w cyfrowym świecie, w procesie surfowania w Internecie narażona jest na istotny problem wyboru informacji i oceny ich wiarygodności. Nierzadko mogą także doświadczać zagubienia w zawikłanym, digitalnym labiryncie sprzecznych treści - tak prawdziwych, jak i fałszywych informacji, mieszanki źródeł pewnych i niepewnych. Można tu przywołać opinię Zbyszko Melosika, który wyraża przekonanie, że w procesie podejścia do informacji młodych ludzi cechuje poszukiwanie jej „w wielu miejscach jednocześnie, lecz czynią to niesystematycznie. Potrafią jednocześnie koncentrować się na wielu rzeczach, nie mając natomiast zdolności koncentracji przez dłuższy czas na tym samym" (Melosik, 2019: 78-79).

Współczesny człowiek otrzymał nowy przydomek - homo informaticus, co oznacza osobę „posiadającą umiejętności niezbędne do działania w przestrzeni medialnej, w której może łatwo i skutecznie pozyskiwać informacje” (Wrońska, 
Tlałka 2015: 398). W dyskursie o konieczności utrzymania się na tzw. informacyjnej fali wyłania się nowa koncepcja luki uczestnictwa (participation gap). Dotyka ona jakościowej sfery wykorzystania dostępnych współcześnie zasobów informacyjnych (Filiciak, 2007). Ukształtowane kompetencje informacyjne otwierają drogę ku wykorzystaniu Internetu jako medium, w którym „użytkownik może być nie tylko konsumentem, ale też wytwórcą treści - może prowadzić do powstania «kultury uczestnictwa», a więc kultury, której uczestnicy samodzielnie wytwarzają, modyfikują i redystrybuują obiekty medialne i zasoby wiedzy" (Filiciak 2007: 5).

Nowe ramy information literacy ACRL pogłębiły definicję kompetencji informacyjnych (włączając m.in. refleksję), przyjmując, że umiejętność korzystania z informacji to „zestaw zintegrowanych zdolności obejmujący refleksyjne odkrywanie informacji, zrozumienie, $w$ jaki sposób informacje są wytwarzane i cenione wraz $\mathrm{z}$ wykorzystaniem informacji $\mathrm{w}$ tworzeniu nowej wiedzy i etycznym uczestnictwie w społecznościach uczenia się" (Pitts, Lehner-Quam 2019: 32).

Zaprezentowane $\mathrm{w}$ artykule rozważania są przyczynkiem do podjęcia pogłębionych badań i analiz information literacy na poziomie kształcenia wyższego z uwzględnieniem rozszerzonej listy kategorii kompetencji zawartych $\mathrm{w}$ dokumencie Framework for Information Literacy. W konkluzji można stwierdzić, że niezależnie od okoliczności technologicznych i zmian w społecznym usytuowaniu procesu wyszukiwania informacji, rozwijanie kompetencji informacyjnych powinno być integralną częścią procesu akademickiego kształcenia młodych dorosłych z pokolenia sieci.

\section{Bibliografia}

Afreen R. (2014), Bring Your Own Device (BYOD) in Higher Education: Opportunities and Challenges, International Journal of Emerging Trends \& Technology in Computer Science, 3(1), s. 233-236.

American Library Association (2000), Information Literacy Competency Standards for Higher Education, http://www.ala.org/acrl/sites/ala.org.acrl/files/content/standards/standards.pdf, dostęp: 14.09.2010.

Association of College and Research Libraries (2015), Framework for Information Literacy for Higher Education, http://www.ala.org/acrl/sites/ala.org.acrl/files/content/issues/infolit/framework1. pdf, dostęp: 08.09.2020.

Babik W. (2010), O natłoku informacji i związanym z nim przeciążeniu informacyjnym, [w:] J. Morbitzer (red.), Człowiek, media, edukacja, Kraków.

Bauman Z., Leoncini T. (2018), Płynne pokolenie, tłum. S. Żuchowski, Warszawa.

Bielska B. (2015), „Magisterkę” kupię. Sprzedawanie i kupowanie prac dyplomowych jako element studenckiej kultury nieuczciwości, Toruń. 
Bochenek M., Lange R. (red.) (2019), Bezpieczne wybory. Badanie opinii o (dez)informacji w sieci, Warszawa, https://www.nask.pl/pl/raporty/raporty/2592,Bezpieczne-wybory-raport-na-temat-dezinformacji-w-internecie.html, dostęp: 12.09.2020.

Boekhorst A.K. (2003), Becoming Information Literate in the Netherlands, Library Review, 52(7), s. $298-309$.

Borawska-Kalbarczyk K. (2015), Kompetencje informacyjne uczniów w perspektywie zmian szkolnego środowiska uczenia się, Warszawa.

Chmielecka E. (2004), Informacja, wiedza, mądrość. Co społeczeństwo wiedzy cenić powinno? Nauka i Szkolnictwo Wyższe, 1(23), s. 7-18.

Eco U. (2007), O bibliotece, tłum. A. Szymanowski, Warszawa.

Filiciak M. (2007), Raport merytoryczny: Wypetniajac lukę uczestnictwa, [w:] M. Filiciak, O. Sutkowska, Raport „Wolontariat dla wiedzy, https://nowoczesnapolska.org.pl/wpcontent/uploads/2008/08/wolontariat_dla_wiedzy_raport.pdf, dostęp: 11.09.2020.

French A.M., Guo Ch., Shim J.P. (2014), Current Status, Issues, and Future of Bring Your Own Device (BYOD), Communications of the Association for Information Systems, 35, s. 191-197.

Galewski T. (2012), Psychologiczne bariery informacyjne w społeczeństwie informacyjnym, Zeszyty Naukowe Uniwersytetu Szczecińskiego, nr 721, Studia Informatica, nr 29, s. 185-197.

Gleick J. (2012), Informacja, bit, wszechświat, rewolucja, Kraków.

Halavais A. (2012), Wyszukiwarki internetowe a społeczeństwo, tłum. T. Płudowski, Warszawa.

Hansen A. (2020), Wyloguj swój mózg, tłum. E. Fabisiak, Kraków.

Hee O., Ping L., Rizal A., Tan K., Fei G. (2019), Exploring Lifelong Learning Outcomes among Adult Learners via Goal Orientation and Information Literacy Self-Efficacy, International Journal of Evaluation and Research in Education, 8(4), s. 616-623.

Jemielniak D. (2019), Socjologia Internetu, Warszawa.

Kopciewicz L. (2016), Zakończenie, [w:] H. Bougsiaa, M. Cackowska, L. Kopciewicz, T. Nowicki, Smartfon i tablet w dziecięcych rękach, Gdańsk, s. 533-537.

Ledzińska M. (2009), Człowiek współczesny w obliczu stresu informacyjnego, Warszawa.

Ledzińska M. (2012), Młodzi dorośli w dobie globalizacji, Warszawa.

Majchrzyk Ł. (2020), Digital, mobile i social media w Polsce w styczniu 2020 roku, https://mobirank. pl/2020/02/23/digital-mobile-i-social-media-w-polsce-w-styczniu-2020-roku, dostęp: 10.09.2020.

Melosik Z. (2019), Pasja i tożsamość naukowca. O władzy i wolności umysłu, Poznań.

Pitts W., Lehner-Quam A. (2019), Engaging the Framework for Information Literacy for Higher Education as a Lens for Assessment in an ePortfolio Social Pedagogy Ecosystem for Science Teacher Education, International Journal of ePortfolio, 9(1), s. 29-44.

Price C. (2018), Jak zerwać ze swoim smartfonem, tłum. K. Różycka, Katowice.

Pyżalski J., Zdrodowska A., Tomczyk Ł., Abramczuk K. (2019), Polskie badanie EU Kids Online 2018, Poznań, https://depot.ceon.pl/bitstream/handle/123456789/17037/EU_Kids_Online_2019_gotowe.pdf?sequence=1\&isAllowed=y, dostęp: 15.09.2020.

Rozkosz E. (2017), Uczenie się badawczych kompetencji informacyjnych. Przegląd literatury, Przegląd Pedagogiczny, 2, s. 66-82.

Siewiorek R. (2014), I powstanie Dreambook, rozmowa Roberta Siewiorka ze Stevenem Poole’em, Gazeta Wyborcza, 28-29 czerwca.

Song Y., Kong S.C. (2017), Affordances and Constraints of Byod (Bring Your Own Device) For Learning and Teaching in Higher Education: Teachers' Perspectives, The Internet and Higher Education, 32, s. 39-46. 
Sparrow B., Liu J., Wegner D.M. (2011), Google Effects on Memory: Cognitive Consequences of Having Information at Our Fingertips, Science, 333, s. 776-778.

Stefanowicz B. (2010), Informacja, Warszawa.

Tadeusiewicz R., (1998), W dymie $i$ we mgle, http://www.solidarnosc.org.pl/ ksn/Docs/rystad.pdf, dostęp: 08.09.2020.

Tanaś M., Kamieniecki W., Bochenek M., Wrońska A., Lange R., Fila M., Loba B., Konopczyński M. (2017), Raport $z$ badania Nastolatki 3.0, Warszawa, https://akademia.nask.pl/publikacje/ Raport_z_badania_Nastolatki_3_0.pdf?, dostęp: 10.09.2020.

Tokarczuk O. (2019), Czuły narrator, przemowa noblowska Olgi Tokarczuk, https://www.nobelprize. org/uploads/2019/12/tokarczuk-lecture-polish.pdf, dostęp: 10.09.2020.

Twenge J.M. (2019), iGen, tłum. O. Dziedzic, Sopot.

Wrońska M., Tlałka E. (2015), Eksplozja informacji versus eksplozja ignorancji, [w:] J. Morbitzer, D. Morańska, E. Musiał (red.), Człowiek, media, edukacja, Dąbrowa Górnicza, s. 398-405. 
